\title{
KARAKTERISTIK FISIKOKIMIA DAN ANTIBAKTERI VIRGIN COCONUT OIL HASIL FERMENTASI BAKTERI ASAM LAKTAT
}

\author{
[Physicochemical and Antibacterial Characteristics of Virgin Coconut Oil Fermented with Lactic Acid Bacteria]
}

\author{
Anton Rahmadi1)*, Ipnatul Abdiah2), Maya Dewi Sukarno2) dan Titin Purnaningsih'3) \\ 1) Jurusan Teknologi Hasil Pertanian, Fakultas Pertanian, Universitas Mulawarman, Samarinda \\ 2) Jurusan Biologi, Fakultas Matematika dan IPA, Universitas Mulawarman, Samarinda \\ 3) Jurusan Biologi, Fakultas Matematika dan IPA, Universitas Palangka Raya, Samarinda
}

Diterima 16 Juli 2013 / Disetujui 05 Desember 2013

\begin{abstract}
Destabilization of oil-water emulsion in coconut milk, in the production of virgin coconut oil (VCO), can be accelerated with the utilization of lactic acid bacteria fermentation. This research was aimed to determine physicochemical and antibacterial characteristics of VCO from coconut

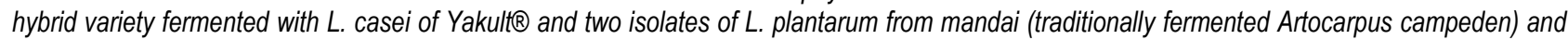
coconut water. The observed physicochemical of VCO included yield, specific gravity, moisture content, saponification value, peroxide value, and free fatty acid. The antibacterial activity was subjected to the well diffusion method against $E$. coli and $S$. aureus with chloramphenicol as the positive control. L. casei yielded the best VCO-BAL at 34.5\% (V/V), while L. plantarum from mandai and coconut water yielded $29.5 \%$ ( $/ \mathrm{V}$ ) and $25.3 \%(\mathrm{~V} / \mathrm{V})$, respectively. VCO-BAL from L. casei had the lightest specific gravity of $0.84 \pm 0.04 \mathrm{~g} \cdot \mathrm{mL}^{-1}$. Average of measured moisture contents (0.03-0.05\%), saponification values (161.3-163.6), peroxide values (0.53-0.86), and free fatty acids (0.11-0.12\%) of the three VCO-BALs were not significantly $(p>0.05)$ different with respect to control. VCO-BAL produced from L. plantarum of coconut water did not exhibit better antibacterial activity compared to control. VCO-BAL from L. casei demonstrated highest antibacterial activity against E. coli, $6.45 \pm 0.50 \mathrm{~mm}$ ( $58.1 \%$ of positive control) and S. aureus, $5.23 \pm 0.40 \mathrm{~mm}(51.3 \%$ of positive control). It is deduced that antibacterial activity from VCO-BAL is contributed by hydrophobic bacteriocins.
\end{abstract}

Keywords: antibacterial activity, L. casei, L. plantarum, physicochemical characteristics, VCO

\begin{abstract}
ABSTRAK
Destabilisasi emulsi minyak-air pada santan kelapa yang menghasilkan virgin coconut oil (VCO) dapat dipercepat dengan bantuan fermentasi bakteri asam laktat. Penelitian ini bertujuan untuk mendapatkan karakteristik fisikokimia dan antibakteri yang dimiliki oleh VCO asal kelapa hibrida dengan metode fermentasi Lactobacillus casei galur komersial Yakult@ dan Lactobacillus plantarum isolat mandai dan blondo kelapa terhadap Escherichia coli dan Staphylococcus aureus. Uji fisikokimia meliputi volume, berat jenis, kadar air, bilangan penyabunan, bilangan peroksida, dan uji asam lemak bebas. Uji aktivitas antibakteri dilakukan dengan metode sumur difusi dengan kloramfenikol sebagai kontrol positif. $L$. casei menghasilkan VCO-BAL dalam persentase volume secara signifikan $(p<0.05)$ lebih besar $(34.5 \% \mathrm{v} / \mathrm{v})$ dibandingkan VCO-BAL asal $L$. plantarum asal isolat mandai $(29.5 \% \mathrm{v} / \mathrm{v})$ dan blondo kelapa $(25.3 \% \mathrm{v} / \mathrm{v})$. VCO-BAL asal L. casei memiliki berat jenis paling ringan $\left(0.84 \pm 0.04 \mathrm{~g} . \mathrm{mL}^{-1}\right)$. Rerata kadar air (0.03-0.05\%), bilangan penyabunan (161.3-163.6), bilangan peroksida (0.53-0.86), bilangan asam lemak bebas (0.11-0.12\%) dari VCOBAL tidak berbeda signifikan $(p>0.05)$ dibandingkan VCO non BAL. VCO-BAL asal L. plantarum isolat blondo kelapa tidak menunjukkan aktivitas antibakteri yang signifikan $(p>0.05)$ berbeda dibandingkan dengan VCO non BAL. VCO-BAL asal L. casei secara signifikan $(p<0.05)$ memiliki zona penghambatan terbaik terhadap E. coli, yaitu $6.45 \pm 0.50 \mathrm{~mm}$ ( $58.3 \%$ dari kontrol positif) dan S. aureus, yaitu $5.23 \pm 0.40$ ( $51.3 \%$ dari kontrol positif), dibandingkan kedua VCO-BAL asal L. plantarum. Aktivitas antibakteri VCO-BAL diduga kuat dipengaruhi oleh bakteriosin hidrofobik.
\end{abstract}

Kata kunci: aktivitas antibakteri, fisikokimia, L. casei, L. plantarum, VCO

\section{PENDAHULUAN}

Virgin coconut oil (VCO) adalah minyak kelapa hasil ekstraksi tanpa menggunakan panas yang menyebabkan perubahan komposisi ataupun karakteristik minyak (APCC, 2009). Emulsi minyak-air pada santan bersifat tidak stabil dikarenakan faktor kuantitas dan kualitas protein yang berfungsi sebagai emulsifier. Proses pemisahan terjadi secara alami dapat dengan bantuan gravitasi, dan diperlukan upaya

*Penulis Korespondensi:

Email: arahmadi@unmul.ac.id; Telp: 0812-5502073 tambahan untuk percepatan deemulsifikasi minyak-air pada santan (Jena et al. 2006; Nour et al. 2009). Santan kelapa mengandung $54 \%$ air, $35 \%$ lemak dan $11 \%$ padatan non lemak (Tansakul dan Chaisawang, 2006). Bakteri asam laktat (BAL) akan memanfaatkan oligosakarida dan protein, mengubahnya menjadi asam laktat dan metabolit-metabolit lainnya (Surono, 2004).

BAL banyak terdapat dalam makanan tradisional, misalnya mandai yang berasal dari Kalimantan (Surono, 2004). BAL ternyata juga dikonfirmasi keberadaannya pada blondo kelapa (Murtius, 2008). L. Plantarum mendominasi spesies BAL yang berasal dari produk tanaman. 
BAL, secara umum, terbukti mampu menginduksi proses pemisahan minyak dan air dari santan kelapa (Che Man et al. 1997). Kondisi ekstraksi tanpa melibatkan panas dan mekanis pada proses fermentasi VCO-BAL dianggap memiliki banyak keuntungan seperti: kadar bilangan penyabunan, bilangan peroksida, dan asam lemak bebas yang rendah, dan sifat antibakteri yang diklaim lebih tinggi (Ali dan Dwiyana, 2005). Hingga saat ini, publikasi yang membandingkan proses fermentasi VCO menggunakan beberapa jenis BAL untuk mengkonfirmasi keunggulan yang dimiliki oleh VCO-BAL masih sangat terbatas. Penelitian ini juga dilakukan sebagai aplikasi BAL hasil isolat makanan tradisional Kalimantan (mandai).

Penelitian ini bertujuan untuk menguji karakteristik fisikokimia dan aktivitas antibakteri yang dimiliki oleh VCO asal kelapa hibrida yang diperoleh dengan metode fermentasi dari $L$. casei galur komersial Yakult@ dan L. plantarum isolat mandai dan blondo kelapa terhadap patogen umum Gram negatif (Escherichia coli) dan Gram positif (Staphylococcus aureus).

\section{BAHAN DAN METODE}

\section{Kelapa}

Buah kelapa hibrida diperoleh dari sekitar wilayah Samarinda, Kalimantan Timur. Kelapa yang digunakan berusia 11-13 bulan sesuai dengan parameter kematangan yang ditetapkan oleh Suhardiman (2000). Kelapa disimpan dalam bentuk utuh selama 1-4 minggu ditempat kering pada suhu ruangan $\left(25-28^{\circ} \mathrm{C}\right)$ sebelum digunakan.

\section{Biakan mikroba}

L. plantarum diperoleh dari hasil fermentasi mandai dan air blondo minyak kelapa dan dimurnikan pada medium MRSA. $L$. casei diperoleh dari minuman Yakult@ . Bakteri uji Escherichia coli dan Staphylococcus aureus diperoleh dari kultur koleksi FMIPA Universitas Mulawarman. Kultur stok isolat-isolat murni dari $L$. plantarum dan $L$. casei dibiakkan di atas medium MRSA (Oxoid, Basingstoke) agar miring yang diberi $\mathrm{CaCO}_{3}$ (Merck) dibagian dasar agar miringnya dan disimpan pada suhu $5^{\circ} \mathrm{C}$ sebelum digunakan. Penyegaran isolat dilakukan di dalam 10 $\mathrm{mL}$ medium MRSB (Oxoid, Basingstoke) pada suhu $37^{\circ} \mathrm{C}$ selama 24 jam. Selanjutnya, isolat yang telah disegarkan (2$3 \%$ ) dinokulasikan di dalam $200 \mathrm{~mL}$ medium susu skim (Nestle, Pasuruan Indonesia) dengan komposisi 10\% susu skim, 1\% pepton (Merck), 2\% glukosa (Merck), dan 2\% yeast extract (Merck). Medium susu skim diinkubasikan pada suhu $37^{\circ} \mathrm{C}$ selama 48 jam. Medium susu skim yang berisi masing-masing isolat bakteri asam laktat akan digunakan pada proses fermentasi VCO.

\section{Pembuatan VCO}

Kelapa hibrida dikupas dan diambil daging buahnya. Sebanyak empat buah kelapa diparut menggunakan mesin pemarut. Selanjutnya kelapa parut direndam dalam air matang $(1: 2, \mathrm{~b} / \mathrm{v})$ bersuhu panas kuku $\left(50^{\circ} \mathrm{C}\right)$ dan diberi tekanan selama 30 menit sebelum disaring. Campuran santan dan ampas tersebut disaring menggunakan kain kasa dan ampasnya dibuang. Santan yang diperoleh didiamkan selama 1 jam, sehingga kepala santan (di bagian atas campuran) terpisah dengan air (di bagian bawah). Kepala santan diambil dan digunakan untuk penelitian.

Kepala santan $(250 \mathrm{~mL})$ digunakan pada masing-masing perlakuan dan diletakkan di dalam gelas Baker. Tiga perlakuan dan satu kontrol digunakan dalam melakukan fermentasi minyak kelapa. Kepala santan tanpa penambahan kultur bakteri (kontrol), dengan penambahan $2 \%$ L. plantarum asal fermentasi mandai yang telah disiapkan pada medium susu skim (perlakukan 1), dengan penambahan $2 \% \mathrm{~L}$. plantarum asal air blondo kelapa yang telah disiapkan pada medium susu skim (perlakukan 2), dan dengan penambahan $2 \% L$. casei yang telah disiapkan pada medium susu skim (perlakukan 3). Gelas Baker ditutup dengan aluminium foil hingga rapat dan setiap santan kelapa tersebut didiamkan pada suhu $37^{\circ} \mathrm{C}$ selama 24 jam. Minyak kelapa murni (VCO) akan berada di lapisan atas dari campuran dan dipisahkan dengan cara disendok secara perlahan. Minyak kelapa dari masing-masing perlakuan fermentasi selanjutnya dipindahkan ke dalam botol gelap dan disimpan di ruangan gelap pada suhu $25^{\circ} \mathrm{C}$ sebelum analisis.

\section{Uji fisikokimia}

Persentase volume (yield) dihitung dari volume VCO yang dihasilkan dari $100 \mathrm{~mL}$ kepala santan. Berat jenis diukur dengan menimbang massa VCO (gram) yang dihasilkan dibandingkan dengan volume VCO (mL). Uji fisikokimia meliputi kadar air, bilangan penyabunan, bilangan peroksida, dan uji asam lemak bebas berdasarkan metode analisis umum lemak atau minyak (Sudarmadji et al. 1996). Hasil uji fisikokimia kemudian dibandingkan dengan standard APCC (2009).

\section{Analisis uji aktivitas antibakteri}

Uji aktivitas antibakteri dilakukan menggunakan metode sumur difusi. Sebanyak $0.5 \mathrm{~mL}$ suspensi $\left(1 \times 10^{6} \mathrm{CFU} / \mathrm{mL}\right)$ bakteri uji, $S$. aureus dan $E$. coli, diinokulasikan ke dalam masing-masing cawan petri dan kemudian ditambahkan medium nutrient agar (NA) dari Merck sebanyak $25 \mathrm{~mL}$ dan kemudian dihomogenkan dan dibiarkan mengeras. Lubang sumur dibuat dengan diameter $0.5 \mathrm{~cm}$ menggunakan pencadang steril. Setiap cawan petri memiliki enam sumur yang ditambahkan dengan $50 \mu \mathrm{L}$ akuades steril (P-), antibiotik kloramfenikol (Kimia Farma, Jakarta) 10mM (P+), VCO non BAL (P0), VCO-BAL asal L. plantarum isolat mandai (P1), VCO-BAL asal $L$. plantarum isolat blondo kelapa (P2), dan VCO-BAL asal L. casei (P3). Cawan petri diinkubasikan pada suhu $37^{\circ} \mathrm{C}$ selama 24 jam. Pengamatan dilakukan dengan mengukur diameter areal bening yang terbentuk di sekeliling sumur sebanyak tiga kali untuk diambil rata-ratanya. Pengamatan dilakukan sebanyak 2 kali ulangan, triplo.

\section{Teknik analisis data}

Data pada setiap pengamatan yang diperoleh kemudian dianalisis menggunakan Microsoft Excel untuk memperoleh nilai standar deviasi, dan SPSS untuk uji lanjut BNT pada taraf galat (a) $5 \%$. 


\section{HASIL DAN PEMBAHASAN}

L. plantarum sebagai BAL hasil seleksi dengan medium MRSA yang terdapat pada mandai dan blondo kelapa memiliki karakteristik morfologi sel berbentuk batang, Gram positif, tidak berspora, non-motil, dan berkatalase negatif. Keberadaan $L$. plantarum pada mandai dan blondo kelapa dikonfirmasi oleh peneliti lainnya (Surono, 2004; Murtius, 2008).

Tabel 1 menyajikan informasi konsentrasi bakteri asam laktat pada medium susu skim setelah diinkubasikan selama 48 jam pada suhu $37^{\circ} \mathrm{C}$ sebelum diintroduksikan kepada kepala santan dan pada fraksi air (blondo) masing-masing perlakuan fermentasi VCO setelah inkubasi selama 24 jam pada suhu $37^{\circ} \mathrm{C}$. Konsentrasi bakteri asam laktat mencapai 6 skala eksponensial per ml susu skim (Tabel 1). Masing-masing biakan starter ini kemudian digunakan untuk memfermentasi kepala santan, sehingga emulsi minyak-air dapat terpecah. Konsentrasi bakteri asam laktat pada santan setelah masa inkubasi 24 jam berada pada 5 skala eksponensial per $\mathrm{mL}$ santan (Tabel 1). Ini membuktikan bahwa L. plantarum dan L. casei dapat hidup dan tumbuh di medium santan, sekalipun kerapatannya menurun sebanyak 1 skala eksponensial dibandingkan dengan medium inokulum susu skim.

Tabel 1. Konsentrasi bakteri asam laktat inokulum dan blondo sisa VCO

\begin{tabular}{ccc}
\hline \multirow{2}{*}{ Isolat } & \multicolumn{2}{c}{ Total Bakteri Asam Laktat (CFU.mL-1) } \\
\cline { 2 - 3 } & Inokulum & 24 Jam Inkubasi \\
\hline P1 & $1.7 \times 10^{6} \pm 5.3 \times 10^{4}$ & $1.7 \times 10^{5} \pm 6.3 \times 10^{4}$ \\
P2 & $1.6 \times 10^{6} \pm 7.5 \times 10^{4}$ & $1.8 \times 10^{5} \pm 7.9 \times 10^{4}$ \\
P3 & $1.8 \times 10^{6} \pm 6.8 \times 10^{4}$ & $1.7 \times 10^{5} \pm 1.0 \times 10^{5}$ \\
\hline
\end{tabular}

P1 $=$ VCO-BAL asal $L$. plantarum isolat mandai, $P 2=$ VCO-BAL asal $L$ plantarum isolat blondo kelapa, P3 $=$ VCO-BAL asal $L$. casei

Terdapat dua proses pemisahan minyak-air pada santan, yaitu: gangguan mikrostruktur pada emulsifier alami dan penurunan $\mathrm{pH}$ sebagai akibat pemanfaatan pati pada santan. Globulin, albumin dan fosfolipid berfungsi sebagai emulsifier alami minyak-air pada santan kelapa (Raghavendra dan Raghavarao, 2010). Salah satu cara kerja dari emulsifier adalah memiliki permukaan aktif (surface active) yang dapat mengelilingi droplet lemak sehingga lemak tetap terdispersi di dalam air (Tangsuphoom dan Coupland, 2009). Gangguan mikrostruktur pada emulsi minyak-air, misalnya akibat pemanfaatan protein dan sekresi protease ekstraseluler oleh BAL, dapat menyebabkan agregasi droplet-droplet minyak (Jirapeangtong et al. 2008).
Kadar pati di dalam santan kelapa berkisar 5.5-6.2\% (Marina et al. 2009). Enzim a-amilosa (99.5 kDa) pada $L$. plantarum bekerja mengkatalisis pemecahan pati menjadi maltotriosa dan maltotetraosa dengan aktivitas mencapai 30$40 \%$ pada suhu $25-30^{\circ} \mathrm{C}$ dibandingkan pada suhu optimumnya $\left(60^{\circ} \mathrm{C}\right)$ (Talamond et al. 2002). Lebih lanjut, maltotriosa dan maltotetraosa dapat dikonversi menjadi asam laktat oleh BAL (Reddy et al. 2008; Petrova et al. 2013). Asam laktat menurunkan $\mathrm{pH}$ santan. Protein-protein santan terkoagulasi akibat tercapainya titik isoelektrik menyebabkan minyak terpisah dari emulsi (Raghavendra dan Raghavarao, 2011).

Persentase volume yang dihasilkan dari proses fermentasi VCO dengan BAL berada pada kisaran $23.0 \%$ hingga $34.5 \%$, dimana VCO-BAL asal L. casei memiliki yield terbaik. L. casei menghasilkan VCO-BAL dalam persentase volume secara signifikan $(p<0.05)$ lebih besar $(34.5 \%)$ dibandingkan VCO-BAL asal $L$. plantarum maupun VCO tanpa penambahan kultur BAL (kontrol).

Berat jenis dari VCO BAL dan non BAL berada pada kisaran 0.84-0.89 g. mL ${ }^{-1}$, dimana VCO-BAL asal L. casei memiliki berat jenis paling ringan dibanding lainnya. VCO-BAL memiliki berat jenis yang lebih rendah dari standar VCO, yaitu 0.91-5-0.920 (APCC, 2009). VCO-BAL asal L. casei memiliki berat jenis paling ringan $\left(0.84 \pm 0.04 \mathrm{~g} \cdot \mathrm{mL}^{-1}\right)$.

Semua VCO yang diproduksi memenuhi kriteria yang ditetapkan APCC (2009) dan mengkonfirmasi temuan sebelumnya (Che Man et al. 1997). Tidak ada perbedaan yang signifikan dari bilangan penyabunan, bilangan peroksida dan bilangan asam lemak bebas dari semua VCO yang diproduksi (Tabel 2). Ini menyebabkan hipotesis pertama ditolak, VCO hasil fermentasi dengan penambahan kultur BAL memiliki karakteristik fisikokimia yang cenderung sama dibandingkan VCO kontrol. Keistimewaan dari VCO-BAL bukan terletak dari karakteristik fisikokimianya. Hasil serupa juga dilaporkan pada penelitian-penelitian yang serupa (Seneviratne et al. 2009; Marina et al. 2009). Pengamatan dilakukan setelah setelah inkubasi selama 24 jam pada suhu $37^{\circ} \mathrm{C}$. Nilai $a$, b, dan $\mathrm{C}$ merupakan kelompok dalam analisis BNT pada taraf $5 \%$. Huruf yang berbeda menunjukkan beda nyata antar perlakuan.

Semua VCO mampu menghambat pertumbuhan E. coli. Tetapi, VCO-BAL asal blondo kelapa tidak berbeda secara signifikan $(p>0.05)$ dibandingkan dengan VCO kontrol. VCOBAL asal $L$. casei memiliki daya hambat yang superior, $58.1 \%$ terhadap kontrol positif, dibandingkan dengan VCO-BAL asal $L$. plantarum isolat blondo kelapa dan mandai, yaitu 27.3 dan $44.6 \%$ terhadap kontrol positif (Tabel 3 )

Tabel 2. Karakteristik fisikokimia dari VCO non BAL dan VCO-BAL asal L. plantarum dan L. casei

\begin{tabular}{ccccccc}
\hline Sampel & Yield $(\% \mathrm{v} / \mathrm{v})$ & $\rho\left(\mathrm{g} \cdot \mathrm{mL}^{-1}\right)$ & KA $(\%)$ & SV & PV & FFA $(\%)$ \\
\hline P0 & $23.0 \pm 0.89^{\mathrm{a}}$ & $0.86 \pm 0.03^{\mathrm{b}}$ & $0.04 \pm 0.01$ & $163.6 \pm 2.23$ & $0.66 \pm 0.40$ & $0.12 \pm 0.02$ \\
P1 & $29.5 \pm 1.21^{\mathrm{b}}$ & $0.87 \pm 0.02^{\mathrm{b}}$ & $0.03 \pm 0.02$ & $162.0 \pm 1.35$ & $0.80 \pm 0.73$ & $0.11 \pm 0.04$ \\
P2 & $25.3 \pm 3.08^{\mathrm{a}}$ & $0.89 \pm 0.03^{\mathrm{c}}$ & $0.05 \pm 0.02$ & $163.1 \pm 2.51$ & $0.86 \pm 0.55$ & $0.11 \pm 0.02$ \\
P3 & $34.5 \pm 2.07^{\mathrm{c}}$ & $0.84 \pm 0.04^{\mathrm{a}}$ & $0.05 \pm 0.01$ & $161.3 \pm 1.82$ & $0.53 \pm 0.40$ & $0.12 \pm 0.03$ \\
\hline
\end{tabular}

$\mathrm{KA}=$ kadar air, $\mathrm{SV}=$ bilangan penyabunan, $\mathrm{PV}=$ bilangan peroksida, $\mathrm{FFA}=$ bilangan asam lemak bebas. $\mathrm{P0}=\mathrm{VCO}$ non $\mathrm{BAL}, \mathrm{P} 1=\mathrm{VCO}-\mathrm{BAL}$ asal $\mathrm{L}$. plantarum isolat mandai, P2 = VCO-BAL asal $L$. plantarum isolat blondo kelapa, P3 = VCO-BAL asal $L$. casei 
Tabel 3. Rata-rata zona hambatan dari tiap perlakuan produksi VCO terhadap bakteri uji Escherichia coli setelah inkubasi 24 jam pada suhu $37^{\circ} \mathrm{C}$

\begin{tabular}{ccc}
\hline \multirow{2}{*}{ Perlakuan } & \multicolumn{2}{c}{ Rata-rata Penghambatan pada Bakteri Uji E. Coli } \\
\cline { 2 - 3 } & $\begin{array}{c}\text { Diameter Zona Hambatan } \\
(\mathrm{mm})\end{array}$ & $\begin{array}{c}\text { \% Penghambatan Rata- } \\
\text { rata vs Kontrol Positif }\end{array}$ \\
\hline $\mathrm{P}(-)$ & 0.00 & 0 \\
$\mathrm{P}(+)$ & $11.10 \pm 0.53$ & 100 \\
$\mathrm{P} 0$ & $2.62 \pm 0.45^{\mathrm{a}}$ & 23.6 \\
$\mathrm{P} 1$ & $4.95 \pm 0.65^{\mathrm{b}}$ & 44.6 \\
$\mathrm{P} 2$ & $3.03 \pm 0.68^{\mathrm{ab}}$ & 27.3 \\
$\mathrm{P} 3$ & $6.45 \pm 0.50^{\mathrm{c}}$ & 58.1 \\
\hline
\end{tabular}

$\mathrm{P}(-)=$ akuades steril, $\mathrm{P}(+)=$ antibiotik kloramfenikol, $\mathrm{PO}=\mathrm{VCO}$ non BAL, $\mathrm{P} 1=$ VCO-BAL asal $L$. plantarum isolat mandai, $P 2=V C O-B A L$ asal $L$. plantarum isolat blondo kelapa, $\mathrm{P} 3=\mathrm{VCO}-\mathrm{BAL}$ asal $\mathrm{L}$. casei. Nilai a,b, dan c merupakan kelompok dalam analisis BNT pada taraf $5 \%$. Huruf yang berbeda menunjukkan beda nyata antar perlakuan

VCO-BAL dan non BAL mampu menghambat pertumbuhan $S$. aureus. Namun, VCO-BAL asal $L$. casei memiliki daya hambat yang secara signifikan $(p<0.05)$ lebih baik, yaitu $51.3 \%$ dibandingkan dengan kontrol positif. VCO-BAL asal $L$. plantarum isolat mandai memiliki daya hambat terhadap $S$. aureus yang signifikan $(p<0.05)$ dibandingkan dengan VCO-BAL asal $L$. plantarum isolat blondo kelapa ataupun VCO non BAL, yaitu $39.7 \%$ terhadap kontrol positif (Tabel 4). Sekali lagi, VCOBAL asal blondo kelapa tidak berbeda secara signifikan $(p>0.05)$ dibandingkan dengan VCO kontrol. Ini membuktikan bahwa tidak semua VCO yang diproduksi dengan penambahan kultur BAL memiliki daya antibakteri yang signifikan lebih baik dibandingkan VCO kontrol.

Tabel 4. Rata-rata zona hambatan dari tiap perlakuan produksi VCO terhadap bakteri uji Staphylococcus aureus setelah inkubas 24 jam pada suhu $37^{\circ} \mathrm{C}$

\begin{tabular}{|c|c|c|}
\hline \multirow[b]{2}{*}{ Perlakuan } & \multicolumn{2}{|c|}{ Rata-rata pada Bakteri Uji S. aureus } \\
\hline & $\begin{array}{c}\text { Diameter Zona Hambatan } \\
(\mathrm{mm}) \\
\end{array}$ & $\begin{array}{c}\text { \% Penghambatan Rata-rata } \\
\text { vs Kontrol Positif }\end{array}$ \\
\hline$P(-)$ & 0.00 & 0 \\
\hline$P(+)$ & $10.20 \pm 0.55$ & 100 \\
\hline $\mathrm{PO}$ & $2.25 \pm 0.56^{a}$ & 22.1 \\
\hline P1 & $4.05 \pm 0.80^{b}$ & 39.7 \\
\hline $\mathrm{P} 2$ & $2.60 \pm 0.57^{\mathrm{ab}}$ & 25.5 \\
\hline P3 & $5.23 \pm 0.40^{c}$ & 51.3 \\
\hline $\begin{array}{l}\mathrm{P}(-)=\text { akuades } \\
\text { VCO-BAL a } \\
\text { isolat blondo } \\
\text { kelompok } \\
\text { menunjukka }\end{array}$ & $\begin{array}{l}\text { ril, } \mathrm{P}(+)=\text { antibiotik kloram } \\
\text { plantarum isolat mandai, } \\
\text { apa, } \mathrm{P} 3=\mathrm{VCO}-\mathrm{BAL} \text { asal } L \text {. } \\
\mathrm{n} \text { analisis BNT pada } \mathrm{t} \\
\text { da nyata antar perlakuan }\end{array}$ & $\begin{array}{l}\text { ikol, P0 = VCO non BAL, P1 } \\
=\text { VCO-BAL asal L. plantarur } \\
\text { sei. Nilai a,b, dan c merupaka } \\
\text { f } 5 \% \text {. Huruf yang berbed }\end{array}$ \\
\hline
\end{tabular}

Tidak semua VCO yang diproduksi dengan penambahan kultur BAL memiliki daya antibakteri yang signifikan lebih baik dibandingkan VCO kontrol. Oleh karena itu, setiap faktor antibakteri kemudian dikonfirmasi dengan literatur-literatur yang telah ada. Aktivitas antibakteri dari VCO-BAL dapat disebabkan oleh asam lemak rantai sedang (asam laurat dan miristat), komponen antioksidan, komponen asam organik dan aromatik, dan bakteriosin hidrofobik.

Asam lemak rantai sedang merupakan ciri khas dari minyak kelapa, terdiri dari asam laurat (43-53\%), asam miristat (16$21 \%)$, asam palmitat $(7.5-10 \%)$, asam kaprilat $(5-10 \%)$, dan asam kaprat (4.5-8\%). Beberapa asam lemak rantai sedang, terutama asam laurat, diklaim memiliki sifat bakterisidal atau mampu menghambat pertumbuhan bakteri patogen (Villarino et al. 2007). Akan tetapi, tidak ada perbedaan signifikan pada komposisi miristat dan laurat antara VCO hasil fermentasi BAL (VCO-BAL) dengan hasil ektraksi mekanis (Seneviratne et al. 2009; Mansor et al. 2012).

Aktivitas antioksidan fenolik dapat dilihat dengan uji 2,2difenil-1-pikrilhidrasil (DPPH) dan uji degradasi deoksiribosa. Dari kedua uji tersebut, aktivitas antioksidan fenolik pada hasil ekstraksi dingin $\left(30^{\circ} \mathrm{C}\right)$ lebih tinggi secara signifikan dibandingkan pada hasil ekstraksi panas $\left(100-120^{\circ} \mathrm{C}\right)$, dengan komponen antioksidan utama berupa asam gallat $(28.1 \pm 10.5 \mathrm{mg} / \mathrm{kg}$ minyak), epigalokatekin $(26.7 \pm 1.7 \mathrm{mg} / \mathrm{kg}$ minyak), dan asam syringic ( $1.4 \pm 0.1 \mathrm{mg} / \mathrm{kg}$ minyak). VCO memiliki kandungan total fenolik 1.8-3.0 kali lebih tinggi dibandingkan dengan refine, bleached, and deodorized coconut oil (RBDCO) (Seneviratne et al. 2009). Tanin, ternasuk didalamnya asam gallat dan epigalokatekin mampu menghambat pertumbuhan $E$. coli, $S$. aureus dan Salmonella (Rodriguez-Vaquero et al. 2011). Komponen-komponen antioksidan tersebut memberikan pengaruh terhadap peningkatan daya hambat dari VCO-BAL sekaligus VCO kontrol (Lacombe et al. 2010). Dari uraian ini dapat disimpulkan bahwa efek antimikrobial akibat antioksidan fenolik VCO bukan menjadi faktor yang membedakan VCO-BAL dan VCO kontrol.

VCO hasil fermentasi diketahui memiliki komponen asam organik dan aromatik seperti asam asetat, asam laktat, heksanal, dan nonanal yang lebih tinggi dibandingkan dengan VCO hasil sentrifugasi (Santos et al. 2011). Asam organik seperti asetat dan laktat mampu menghambat pertumbuhan bakteri patogen (Carpenter et al. 2011). Hexanal dan 2-hexenal mampu mengurangi kecepatan tumbuh dari populasi mikroba mesotrofik dan psikrotropik pada buah olah minimal di suhu dingin (Patrignani et al. 2008). Nonanal dan a,ß-unsaturated aldehid juga menunjukkan penghambatan pada $S$. aureus dan Salmonella choleraesuis disamping menunjukkan daya antifungal (Kubo et al. 2004). Diduga, komponen-komponen asam organik dan aromatik tersebut juga memberikan pengaruh terhadap peningkatan daya hambat dari VCO-BAL dibandingkan dengan VCO kontrol. Efek antibakteri senyawa-senyawa aromatik bersifat lebih lemah dibandingkan asam organik (Kubo et al. 2004). Kelarutan asam asetat dan laktat lebih baik pada air dibandingkan minyak dan kadar air dari VCO berkisar pada 0.1-0.5\% (Che Man et al. 1997). Kandungan asam laktat di dalam VCO-BAL hanya berkisar $0.03-0.37 \%$ dengan inokulum starter $L$. plantarum sebanyak $0-5 \%$ dari total volume santan (Che Man et al. 1997). Dapat disimpulkan bahwa efek dari asam organik dan aromatik terhadap aktivitas antibakteri dari VCO cenderung terbatas.

Pada minyak kelapa murni hasil fermentasi bakteri asam laktat, juga terkandung bakteriosin yang diproduksi oleh BAL. Bakteriosin dapat menghambat pertumbuhan bakteri yang merugikan seperti Escherichia coli, Listeria monocytogenes, dan Staphylococcus aureus (Surono, 2004). Plantarisin adalah bakteriosin dengan bobot $3.5 \mathrm{kDa}$ yang umum ditemukan sebagai metabolit dari L. plantarum (Gong et al. 2010). Plantarisin dapat dikarakterisasi lebih lanjut menurut gugus- 
gugus peptida hidrofobiknya. Sebagai contoh, plantarisin C, memiliki terdiri dari banyak asam amino glisin yang bersifat hidrofobik, sehingga kelarutannya lebih baik di lemak atau minyak (Cotter et al. 2005). Tidak semua isolat L. plantarum mampu menghasilkan plantarisin $C$, namun dapat juga plantarisin EF, JK, S, T atau W yang bersifat kurang hidrofobik dibandingkan plantarisin C (Anderssen et al. 1998; Tsapieva et al. 2011). Produksi spesies plantarisin oleh $L$. plantarum dipengaruhi oleh tiga sistem transduksi sinyal, yaitu peptida feromon (PInA), kinase protein histidin (PInB), dan duga reseptor homolog (PInC dan PInD) (Risoen et al. 2001; Zhao et al. 2006).

Lebih lanjut, bakteriosin memiliki kemampuan untuk menyesuaikan kelarutannya terhadap medium (Abriouel et al. 2001). Sebagai contoh, bakteriosin AS-48 dari Enterococcus faecalis subsp. liquefaciens dalam kondisi $\mathrm{pH}$ netral banyak ditemui sebagai oligomer yang bersifat hidrofobik. Pada $\mathrm{pH}$ asam, bakteriosin ini berbentuk monomerik (Sanchez-Barrena et al. 2003; Abriouel et al. 2001). Oligomerisasi bakteriosin juga menyebabkan mudahnya bakteriosin masuk kedalam membran bipeptida dari bakteri Gram negatif dan positif yang berimplikasi pada pembentukan pori-pori membran dari bakteri-bakteri tersebut. Plantarisin A pada konsentrasi nanomolar dapat menyebabkan gangguan zweitter ionik fosfolipid pada membran sel (Zhao et al. 2006).

Diduga $L$. plantarum dari hasil isolat mandai memproduksi plantarisin hidrofobik dibandingkan isolat dari blondo kelapa. Sebagai akibatnya, VCO-BAL asal L. plantarum isolat mandai memiliki daya inhibisi yang lebih besar (40\%) dibandingkan VCO-BAL asal L. plantarum isolat blondo kelapa (25-30\%). $L$. casei diduga memproduksi bakteriosin hidrofobik, sehingga daya hambat mikrobialnya paling baik (50-55\%) dibandingkan dengan VCO-BAL asal L. plantarum. Dari uraian ini, hipotesis kedua yang menyatakan: VCO hasil fermentasi dengan penambahan kultur BAL memiliki daya antibakteri yang lebih baik dibandingkan VCO hasil ekstraksi tanpa penambahan kultur BAL (kontrol) dapat diterima, dengan syarat bahwa kultur BAL tersebut mampu memproduksi bakteriosin hidrofobik. Proses pembuktian keberadaan bakteriosin hidrofobik pada $L$. casei dan L. plantarum isolat mandai akan dilakukan sebagai lanjutan dari hasil diskusi ini.

\section{KESIMPULAN}

L. casei menghasilkan VCO-BAL dalam persentase volume secara signifikan lebih besar (34.5\%) dibandingkan VCO-BAL asal L. plantarum asal isolat mandai (29.5\%) dan blondo kelapa (25.3\%). VCO-BAL asal L. casei memiliki berat jenis paling ringan $(0.84 \pm 0.04 \mathrm{~g} / \mathrm{mL})$. Rata-rata kadar air (0.03-0.05\%), bilangan penyabunan (161.3-163.6), bilangan peroksida (0.53$0.86)$, bilangan asam lemak bebas $(0.11-0.12 \%)$ dari VCO-BAL tidak berbeda signifikan dibandingkan VCO non BAL. Keistimewaan dari VCO-BAL tidak terletak dari karakteristik fisikokimianya. Tidak semua VCO yang diproduksi dengan penambahan kultur BAL memiliki daya antibakteri yang signifikan lebih baik dibandingkan VCO kontrol. VCO-BAL asal L. Plantarum isolat blondo kelapa tidak menunjukkan aktivitas antibakteri yang signifikan berbeda dibandingkan dengan VCO non BAL. VCO-BAL asal $L$. casei secara signifikan memiliki zona penghambatan terbaik terhadap $E$. coli, yaitu $6.45 \pm 0.50$ $\mathrm{mm}(58.1 \%$ dari kontrol positif) dan $S$. aureus, yaitu $5.23 \pm 0.40$ (51.3\% dari kontrol positif), dibandingkan kedua VCO-BAL asal L. Plantarum. Aktivitas antibakteri VCO-BAL diduga kuat dipengaruhi oleh bakteriosin hidrofobik.

\section{UCAPAN TERIMA KASIH}

Ucapan terima kasih disampaikan kepada Dirjen DIKTI dalam pembiayaan melalui skema Penelitian Dosen Muda periode 2006/2007 serta FMIPA Unmul yang telah memberikan fasilitas untuk berkarya.

\section{DAFTAR PUSTAKA}

Abriouel H, Valdivia E, Gálvez A, Maqueda M. 2001. Influence of physico-chemical factors on the oligomerization and biological activity of bacteriocin AS-48. Curr Microbiol 42: 89-95. DOI: 10.1007/s0028403335.

Ali A, Dwiyana Z. 2005. Bakteri Asam Laktat Potensi dan Peranan dalam Produk Pangan dan Kesehatan, Prosiding Pelatihan Bakteri Asam Laktat. Universitas Hasanuddin Makassar.

Anderssen EL, Diep DB, Nes IF, Eijsink VGH, Nissen-Meyer J. 1998. Antagonistic activity of Lactobacillus plantarum C11: two new two-peptide bacteriocins, plantaricins EF and JK, and the induction factor plantaricin A. Appl Environ Microbiol 64: 2269-2272.

APCC. 2009. APCC Standards for virgin coconut oil. http:// www.apccsec.org/document/VCNO.PDF. [3 Oktober 2013].

Carpenter CE, Smith JV, Broadbent JR. 2011. Efficacy of washing meat surfaces with $2 \%$ levulinic, acetic, or lactic acid for pathogen decontamination and residual growth inhibition. Meat Sci 88: 256-260. DOI: 10.1016/j. meatsci.2010.12.032.

Che Man YB, Abdul Karim MIB, Teng CT. 1997. Extraction of coconut oil with Lactobacillus plantarum 1041 IAM. J Am Oil Chem Soc 74: 1115-1119. DOI: 10.1007/s11746-997-00330.

Cotter PD, Hill C, Ross RP. 2005. Bacterial lantibiotics: strategies to improve therapeutic potential. Curr Protein Peptide Sci 6: 61-75. DOI: 10.2174/1389203053027584.

Gong, HS, Meng XC, Wang H. 2010. Plantaricin MG active against gram-negative bacteria produced by Lactobacillus plantarum KLDS1.0391 isolated from "Jiaoke", a traditional fermented cream from China. Food Control 21: 89-96. DOI:10.1016/j.foodcont.2009.04.005.

Jena S, Das H. 2006. Modeling of particle size distribution of sonicated coconut milk emulsion: Effect of emulsifiers and sonication time. Food Res Int 39: 606-611. DOI: 10.1016/ j.foodres.2005.12.005.

Jirapeangtong K, Siriwatanayothin S, Chiewchan N, 2008. Effect of coconut sugar and stabilizing agents on stability 
and apparent viscosity of high-fat coconut milk. J Food Eng 87: 422-427. DOI: 10.1016/j.jfoodeng.2008.01.001.

Kubo I, Fujita KI, Kubo A, Nihei KI, Ogura T. 2004. Antibacterial activity of coriander volatile compounds against Salmonella choleraesuis. J Agric Food Chem 52: 3329-3332. DOI: 10.1021/jf0354186.

Lacombe A, Wua VCH, Tyler S, Edwards K. 2010. Antimicrobial action of the American cranberry constituents; phenolics, anthocyanins, and organic acids, against Staphylococcus aureus 0157:H7. Int J Food Microbiol 139: 102-107. DOI: 10.4103/0973-1296.99286.

Mansor TST, Che Man YB, Shuhaimi M, Abdul AMJ, Ku Nurul FKM. 2012. Physicochemical properties of virgin coconut oil extracted from different processing methods. Int Food Res 19: $837-845$.

Marina AM, Che Man YB, Nazimah SAH, Amin I. 2009. Chemical properties of virgin coconut oil. J Am Oil Chem Soc 86: 301-307. DOI: 10.1007/s11746-009-1351-1.

Murtius WS. 2008. Pemanfaatan Blondo Sebagai Starter dalam Pembuatan Minuman Probiotik. [Tesis]. Program Pasca Sarjana Universitas Andalas.

Nour AH, Mohammed FS, Yunus RM, Arman A. 2009. Demulsification of virgin coconut oil by centrifugation menthod: a feasibility study. Int J Chem Technol 1: 59-64. DOI: 10.3923/ijct.2009.59.64.

Patrignani F, lucci L, Belletti N, Gardini F, Guerzoni ME, Lanciotti R. 2008. Effects of sub-lethal concentrations of hexanal and 2-(E)-hexenal on membrane fatty acid composition and volatile compounds of Listeria monocytogenes, Escherichia coli, Salmonella enteritidis and Staphylococcus aureus. Int J Food Microbiol 123: 1-8. DOI: 10.1016/j.ijfoodmicro.2007.09.009.

Petrova P, Petrov K, Stoyancheva G. 2013. Starch modifying enzymes of lactic acid bacteria-structures, properties, and applications. Starch/Stärke 65: 34-47. DOI: 10.1002/star. 201200192

Raghavendra SN, Raghavarao, KSMS. 2010. Effect of different treatments for the destabilization of coconut milk emulsion. J Food Eng 97: 341-347. DOI: 10.1016/j.jfoodeng.2009. 10.027 .

Raghavendra SN, Raghavarao KSMS. 2011. Aqueous extraction and enzymatic destabilization of coconut milk emulsions. J Am Oil Chem Soc 88: 481-487. DOI: 10.1007/ s11746-010-1695-6.

Reddy G, Altaf MD, Naveena BJ, Venkateshwar M, Kumar EV. 2008. Amylolytic bacterial lactic acid fermentation - A review. Biotechnol Adv 26: 22-34. DOI: 10.1016/j.biotechadv.2007. 07.004 .

Risoen PA, Johnsborg O, Diep DB, Hamoen L, Venema G, Nes IF. 2001. Regulation of bacteriocin production in Lactobacillus plantarum depends on a conserved promoter arrangement with consensus binding sequence. Mol Genet Genomics 265: 198-206. DOI: 10.1007/s004380000397.

Rodriguez-Vaquero MJ, Fernández PAA, De Nadra MCM. 2011. Effect of phenolic compound mixtures on the viability of Listeria monocytogenes in meat model. Food Technol Biotechnol 49: 83-88.

Sanchez-Barrena, MJ, Martınez-Ripoll M, Galvez A, Valdivia E, Maqueda M, Cruz V, Albert A. 2003. Structure of bacteriocin as-48: from soluble state to membrane bound state. $\mathrm{J} \mathrm{Mol}$ Biol 334: 541-549. DOI: 10.1016/j.jmb.2003.09.060.

Santos JER, Villarino BJ, Zosa AR, Dayrit FM. 2011. Analysis of volatile organic compounds in virgin coconut oil and their sensory attibutes. Philippine J Sci 140: 161-171.

Seneviratne KN, Hapuarachchi CD, Ekanayake S. 2009. Comparison of the phenolic-dependent antioxidant properties of coconut oil extracted under cold and hot conditions. J Food Chem 114: 1444-1449. DOI: 10.1016/j. foodchem.2008.11.038.

Sudarmadji S, Haryono B, Suhardi. 1996. Analisis Bahan Makanan dan Pertanian. Penerbit Liberty, Yogyakarta.

Suhardiman P. 2000. Bertanam Kelapa Hibrida. Penebar Swadaya, Jakarta.

Surono IS. 2004. Probiotik: Susu Fermentasi dan Kesehatan. YAPMMI, Jakarta.

Talamond P, Desseaux V, Moreau Y, Santimone M, MarchisMouren G. 2002. Isolation, characterization and inhibition by acarbose of the a-amylase from Lactobacillus fermentum: comparison with $L b$. manihotivorans and $L b$. plantarum amylases. Comp Biochem Physiol B 133: 351-360. DOI: 10.1016/S1096-4959(02)00157-4.

Tangsuphoom N, Coupland JN. 2009. Effect of thermal treatments on the properties of coconut milk emulsions prepared with surface-active stabilizers. Food Hydrocolloid 23: $1792-1800$.

Tansakul A, Chaisawang P. 2006. Thermo physical properties of coconut milk. J Food Eng 73: 276-280. DOI: 10.1016/j. foodhyd.2008.12.001

Tsapieva A, Duplik N, Suvorov A. 2011. Structure of plantaricin locus of Lactobacillus plantarum 8P-A3. Beneficial Microbes 2: 255-261. DOI: 10.3920/BM2011.0030.

Villarino BJ, Dy LM, Concepcion M, Lizada C. 2007. Descriptive sensory evaluation of virgin coconut oil and refined, bleached and deodorized coconut oil. LWT-Food Sci Technol 40: 193-199. DOI: 10.1016/.J.Iwt.2005.11.007.

Zhao H, Sood R, Jutila A, Bose S, Fimland G, Nissen-Meyer J, Kinnunen PKJ. 2006. Interaction of the antimicrobial peptide pheromone Plantaricin A with model membranes: Implications for a novel mechanism of action. Biochim Biophys Acta 1758: 1461-1474. DOI: 10.1016/j.bbamem. 2006.03.037. 